\title{
DO SOCIÓLOGO ERUDITO AO SOCIÓLOGO DE MERCADO: patrocínio e construção de redes na Sociologia brasileira
}

\section{Eladio Antonio Oduber Palencia}

Curso: Doutorado em Sociologia

Data de defesa da tese: 28 de janeiro de 2005

Orientador: Prof. Dr. Michelangelo Giotto Santoro Trigueiro

\section{Resumo}

Esta tese trata da estruturação material da Sociologia no Brasil, suas estratégias para procurar patrocínios e o estabelecimento das suas redes de apoio. Analisa quais são, na atualidade, os resultados deste processo, desenha um cenário de tendências e sugere rumos possíveis para a reconquista do valor social da Sociologia brasileira.

O reconhecimento das variáveis patrocínio e rede de apoio colabora na explicação do surgimento de determinadas controvérsias éticas ou teóricas, escolhas metodológicas e estilos de sociologia. Surgiram, deste estudo, quatro tipos de sociologia brasileira que podem ser resumidos como segue.

Sociologia autofinanciada: caracterizada pela fragilidade ou ausência de laços com a instituição universitária, uma vez que as obras foram financiadas num quadro de mecenato familiar. Os autores desta sociologia desenvolveram suas carreiras intelectuais valendose basicamente do seu patrimônio material e social.

Sociologia "humboldtiana": patrocinada principalmente pelo Estado, define-se pelo seu estilo especulativo e seu escasso vínculo com o mundo produtivo. O sociólogo "humboldtiano" desenvolveu a habilidade de escapar ao controle dos seus patrocinadores e quando 
não o conseguiu, traçou, sem muito sucesso, estratégias para procurar outros patrocínios.

Sociologia dos centros: surge como saída à crise de patrocínio para as ciências sociais nos primeiros anos do regime militar, desenvolveu conhecimentos de economia, estatística e se habilitou no planejamento de pesquisas longitudinais de caráter quantitativo. Esta Sociologia conquista patrocínios fora da academia. Encontra-os principalmente no âmbito governamental, através da burocracia institucional nacional e internacional.

Sociologia profissional: caraterizada pelas estratégias individuais de sobrevivência dos sociólogos, opõe-se às estratégias institucionais de conquista do patrocínio. Os sociólogos, decepcionados com a baixa profissionalização da carreira, adotam a saída do "multi-empreguismo" ou abandonam a Sociologia para começar o aprendizado de outras profissões. A Sociologia de mercado surge como um subtipo neste processo de profissionalização da Sociologia no Brasil. Esta sociologia estabelece contínuas negociações com o mundo produtivo e as informações por ela produzidas deverão ser avaliadas pela utilidade que representam para seus patrocinadores, numa aplicação particular e no contexto desta aplicação.

Palavras-chave: Sociologia brasileira, redes de apoio, patrocínio, profissionalização, sociólogo. 